\title{
STANDARD AND CONFORMITY: THE STRATEGIC PERSPECTIVE OF THE LOCAL GOVERNMENT'S ROLES IN THE INDUSTRY COMPETITIVENESS
}

\author{
Dona Budi Kharisma, M. Najib Imanullah, Pranoto \\ Faculty of Law, Universitas Sebelas Maret \\ Email: donabudikharisma@staff.uns.ac.id
}

\begin{abstract}
The Agreement on the Technical Barriers to Trade (TBT Agreement) WTO and The ASEAN Economic Community (AEC) The Blueprint envisions the transformation of the WTO and ASEAN region through the facilitation of the free flow of goods and services. With tariffs declining to near-zero levels, non-tariff barriers are increasingly focused on coordination by member-countries. However, the quality of goods / services becomes a central issue that determines the market entry. Therefore, TBT agreement and AEC Blueprint require fulfillment of Standards and Conformity Assessment to guarantee the quality of goods or services. On the one hand, the low level of compliance of business actors in applying SNI (Indonesian National Standards) represents of the low level of Indonesian industry competitiveness in international level. Thus, specific government's policies are required, one of which is that dealing with the strategic roles of local government to support products manufactured by national industries to break through global markets. Some strategies for strengthening local policies in national standardization include: (a) constructing local regulations governing Standards and Conformity assessment; (b) implementing mandatory SNI to leading local products; (c) Strengthening mutual cooperation between local government and related stakeholders.
\end{abstract}

Key words: Industry Competitiveness, Conformity

\section{A. INTRODUCTION}

The Agreement on Technical Barriers to Trade (TBT Agreement) agreed upon by the WTO member countries defined standard as a document approved by a recognized body, that provides, for common and repeated use, rules, guidelines or characteristics for products or related processes and production methods, with which compliance is not mandatory. It may also include or deal exclusively with terminology, symbols, packaging, marking or labeling requirements as they apply to a product, process or production method (Annex 1 of TBT Agreement). Meanwhile, WTO detailed the notion of conformity assessment procedures: any procedure used, directly or indirectly, to determine the relevant requirements in technical regulations or standards are fulfilled. Conformity assessment procedures include, inter alia, procedures for sampling, testing and inspection; evaluation, verification and assurance of 
conformity; registration, accreditation and approval as well as their combinations (Annex 1 TBT Agreement).

The notion of standard in Indonesia is stipulated in Law Number 20 of 2014 on Standards and Conformity Assessment. In reference to Article 1 Section 2, the Conformity Assessment is defined as an activity to assess that the goods, services, systems, processes, and personals have met the referred requirements. Meanwhile, the notion of standard set forth in Article 1 Section 3 is technical requirements or anything standardized, including procedures and methods drawn up by consensus of all parties/ governments/ international decisions with regards to safety, security, health, environment, the development of science and technology, experience, and current and future developments to gain the maximum benefit. The standards applicable in Indonesia are the Indonesian National Standards (SNI). As stipulated in Article 1 Section 7 of Law Number20 of 2014, SNI is, by definition, standards which were determined by Badan Standardisasi Nasional (BSN-National Standardization Agency of Indonesia) and is valid in the territory of the Unitary State of the Republic of Indonesia.

The standards generally take the forms of voluntary and mandatory standards. Standards serve as a guideline for business actors in the production process to produce products with certain quality according to market needs and development of technology. As trade barriers diminish in terms of tariffs, nontariff roles such as standards are becoming increasingly important.

Standards and Conformity assessment presents as a strategic issue in today's international trade context since the quality of goods/services becomes the central issue that determines the market entry. In the context of the WTO and AEC, the fulfillment of the standards for goods/ services becomes the key in order for a local product to enter the another county's market.

In the Agreement on Technical Barriers to Trade (TBT Agreement) agreed upon by the WTO member countries, the fulfillment of the standards is not an attempt to exercise counterproductive trade protection against multilateral trade. In TBT Agreement, compliance with standards aims at national security, prevention of fraudulent practices and protection of human health or safety, life or health of animals or plants, or the environment. It is regulated in Article 2.2 TBT Agreement stating that: 
"Members shall ensure that technical regulations are not prepared, adopted or applied with a view to or with the effect of creating the unnecessary obstacles to international trade. For this purpose, technical regulations shall not be more traderestrictive than necessary to fulfill a legitimate objective, taking account of the risks non-fulfillment would create. Such legitimate objectives are, inter alia: national security requirements; the prevention of deceptive practices; protection of human health or safety, animal or plant life or health, or the environment. In assessing such risks, relevant elements of consideration are, inter alia: available scientific and technical information, related processing technology or intended end-uses of products.

A consequence of the removal of tariff and non-tariff barriers to trade, WTO member countries are required to apply Standards and Conformity assessment in the case of exported products to other countries. Although the TBT Agreement has been agreed on the international standards of a product/service, the target country still has the autonomy to determine the standards of goods/services in accordance with its relevant national policies, especially those directly related to health, security, and environmental protection (McDaniels, D., \& Karttunen, M., 2016: 3).

The same thing has been agreed by ASEAN countries. ASEAN Economic Community (AEC) as a form of trade transformation among ASEAN countries has made various efforts to realize more dynamic and stronger market segments of the global market. One of the efforts is implementing Standards and Conformity Assessment. Article 4 of the ASEAN Policy Guideline on Standards and Conformance mandates that:

Member countries should give special attention to implement all the standards, technical regulations and conformity assessment measures as stated in the Bali Concord II, the Recommendation of the High Level Taskforce on ASEAN Economic Integration and the documents for fast-track integration of the priority sectors including the ASEAN Framework Agreement for the Integration of Priority Sectors, its protocols and roadmaps.

This was quickly responded by the Indonesian government by issuing President Instruction Number 6 of 2014 on the Improvement of National Competitiveness in order to encounter the Economic Society Association of Southeast Asian Nations. Such president instruction mandates the development of national industries, which focuses on the application 
of $S N I$ as one of the strategies to improve national competitiveness in the implementation of AEC.

The implementation of Standards and Conformity Assessment is based on the free market as an impact following the trade globalization of the WTO and ASEAN countries. Society is encouraged to engage in extensive interactions and transactions in a variety of strategic areas. WTO and AEC have consequences on the goods and/or services that enter Indonesia without trade barriers so that various types of products will be widely circulated in the market. With the increasingly diverse products of goods circulated in the markets, both local and foreign products, it is necessary to guarantee te quality to avoid harming consumers, both domestic and foreign consumers. Assurance of the quality of a good can be ensured by the implementation of Standards and Conformity Assessment. It serves as a requirement for local products to break through the free markets of WTO and MEA. This condition means that improving national competitiveness is important to do.

Considering the importance of competitiveness, it is included as top three priorities of the nine visions, missions and action programs initiated by President Joko Widodo, known as Nawacita. The three priorities related to competitiveness include (1) improving the quality of human life; (2) increasing people's productivity and competitiveness in international markets; and (3) realizing economic independence by activating strategic sectors of the domestic economy.

Various government's breakthroughs and innovations in enhancing national competitiveness to drive industrial growth have been carried out. Deregulation through the package of economic policies launched by the government is an attempt to overcome this problem. The Ministry of Industry has also undertaken several steps, one of which is the improvement of the quality of Human Resources (HR). In addition, the Ministry of Finance has also encouraged industry competitiveness through fiscal policies, for example, tax incentives such as tax allowance and tax holiday. Similarly, from the custom side, a number of incentives have also been provided, such as the establishment of a bonded logistics center and special economic zones. Still, the effort was not insufficient. According to the Global Competitiveness Index 2016-2017 released by the World Economic Forum, Indonesia's ranking dropped from 37 th position to 41 st although the score, 4.52, remained the same. (Kompas, February 09, 2017). 
Various policies that have been done by the government should be appreciated. However, efforts should be made from various sides so that Indonesian industry can be more competitive in working on domestic and export markets. Never do things like support in one aspect will be useless because of forgetting to fix the industrial problem in another aspect. One of them is the effort to apply Standards and Conformity Assessment as access to another country's market. The implementation of Standards and Conformity Assessment is a phenomenon of strategic change in the field of international trade that requires a special policy of central and local governments so that products produced by national industry can break through the global markets.

In Indonesia, Standards and Conformity Assessment is regulated in various laws and regulations: Law Number 8 of 1999 on Consumer Protection, Law Number 36 of 2009 on Health, Law Number 18 of 2012 on Food, Law Number 3 of 2014 on Industry, Law Number7 of 2014 on Trade and Law Number 20 of 2014 on Standards and Conformity Assessment.

\section{B. RESEARCH PROBLEMS}

In the Standards and Conformity Assessment Act, central and local governments take the responsibility for the implementation of Standards and Conformity Assessment. Central government plays roles in planning, formulating, stipulating, implementing, enforcing, maintaining, and supervising Standards and Conformity Assessment activities. What need to be questioned are what strategic roles local government have in industry competitiveness, especially in the implementation of Standards and Conformity Assessment and how the policy needs to be applied by local government to build a policy construction to support the national industry. The results of this study are important, first to build a policy construction that serves as an offensive strategy to prepare leading local products that comply with Standards and Conformity Assessment to break through international markets, and second, to suggest defensive strategies to protect society and business actors in local areas from the invasion of products of WTO and ASEAN countries that do not have the standard quality.

\section{RESEARCH METHODS}

The present research belongs to normative law research with such approaches as legal act approach, case approach, comparative approach, and conceptual approach (Marzuki, P., 
M., 2014: 133). The law materials used included primary law materials comprising the relevant legal act, and secondary law material comprising reference materials. Data were analyzed using qualitative juridical analysis, an analysis based on the interpretation of law, the reasoning of law, and the argumentation of law.

\section{RESEARCH RESULTS OF THE RESEARCH AND DISCUSSION}

\section{Strategic Roles of Local Government in Determining Standards and Conformity} Assessment

The presence of WTO and AFC as forms of transformation of international trade provides opportunities and easiness for business actors and society to make trade transactions of both goods and services freely without any barriers. Such situation demands Indonesian nation to have strong competitiveness. In reference to the fact, therefore, economic competitiveness which allows contribution to sustainable economic growth is required. Either high or low national competitiveness depends very much on local competitiveness. For that reason, several attempts to improve local competitiveness are also important to make. Developing leading local sectors which can raise economic growth can be a solution to enhance local competitiveness.

The purpose of local economic competitiveness is to provide sustainable economic growth by developing leading sectors based on local potentials and needs to improve the wellbeing of society. To keep pace with the implementation of local autonomy, government's role to attempt to improve local competitiveness have become significant and strategic.

To improve competitiveness, local government plays a significant role in determining standards and conformity assessment due to standards' close relation to competitiveness. Standardization is a means of improving quality of production efficiency, expediting trade transactions, and realizing fair and transparent competitiveness (Article 3 of Law Number 20 of 2014). The implementation of product standards by business actors is closely related to product capabilities both in local and global markets. The determination of product standards in a production process guarantees that products circulated in markets are those which complied with standard quality and provides environmental and consumer protection/ security. 
Data of the $B S N$ provide an overview of Indonesia's low industrial competitiveness. Kukuh S Achmad, a deputy of Department of Accreditation and Standard Implementation of the BSN, outlined that random sampling conducted by the BSN in 2016 to 13 cities in Indonesia indicated that the mandatory SNI had been applied for $46 \%$ of products circulated in markets. Meanwhile, data of Ministry of Trade signify lower percentage (42\%). Most electrical devices and cables for which the mandatory SNI should be applied have not considered the SNI (Kompas, April 03, 2017). The involvement of all parties, including local government is required to encourage the improvement and the implementation of the standards as an attempt to enhance competitiveness.

In the context of local competitiveness, some local government's strategic roles in implementing standards and conformity assessment include:

a. Proposing the formulation of $S N I$ to the $B S N$ in order to enhance the quality of leading local goods and services

Under Article 10 section (5) of Law Number 20 of 2014, local government can propose the formulation of $S N I$ to the $B S N$ on leading local products. Such formulation involves some processes from standard drafting to stipulating. Based on the society's needs of standards, local government can propose the issue to the $B S N$ through Program Nasional Perumusan Standar (PNPS - a national program for standard formulation). This local government's role is assumed to be strategic in improving quality of leading local products by focusing requirements needed to ensure protection of the public interests and environment. Minimum requirements for products should be fulfilled with regards to the needs and characteristics of Indonesian nation, and break through global markets.

b. Providing a guidance for development of Lembaga Penilaian Kesesuaian (LPKConformity Assessment Institution)

Conformity Assessment involves activities to ensure that products, services, systems, processes, and personals have met the referred requirements. An institution responsible for the Conformity Assessment is the LPK. Article 54 of Law Number 20 of 2014 mandates such institutions as the $L P K$, the $B S N$, ministry, nonministry institutions, and/or local government with regards to the needs of markets and society. 
The guidance for the development of the $L P K$ is carried out to support the implementation of standards to be further accredited by Komite Akreditasi Nasional ( $K A N$-National Committee on Accreditation). It is a nonstructural institution under Accreditation Department of the LPK.

c. Improving competencies of human resources in the field of Standards and Conformity Assessment

Article 56 of Law Number 20 of 2014 states that local government plays role in enhancing competencies of human resources in the field of Standards and Conformity Assessment. The human resources refer to society not only as consumers, but also as business actors or producers. The low culture of quality in Indonesian society presents as a problem in determining standards, leading to society's nonoptimal preference to purchase domestic products, particularly SNI-compliant products. Such market condition exerts an influence on business actors. They will prioritize market demand and prefer producing nonSNI-compliant goods due to high market demand and lower production cost. However, the products have no competitiveness. The low level of voluntary implementation of SNI by business actors is caused by the absence of actual evidence of such implementation which proved the business enhancement. The improvement of competencies of human resources in the field of Standards and Conformity Assessment aims at raising society's and business actors' awareness and education on standardization and conformity assessment to develop their commitment to implement SNI. Such role is important to build the culture and competency of quality for Indonesian nation.

d. Supervising goods, services, systems, processes, and personals with SNI certificate and/or compliance with SNI and/or certificate of conformity

Supervision of circulated goods in markets is important to perform by local government as implementer considering excessive number of circulated goods recalcitrant to quality standards. Such goods do not only harm consumers' health and security, but also disadvantage business actors who apply standards in production process. Article 58 of Law Number 20 of 2014 gives authority to local government to coordinate with related institutions in addition to the BSN, Badan Pengawas Obat dan Makanan (BPOM-Food and Drugs Supervisory Board) in conducting supervision 
on goods/ services. Other local government's authorities regarding the supervisory function include: (1) supervising goods circulated in domestic markets; (2) examining the quality of goods if required; and (3) giving sanctions based on prevailing laws and regulations.

The implementation of standards, conformity assessment, as well as metrology is getting demanding, particularly to protect society's interests and improve competitiveness of the nation. With Indonesia's membership in WTO, the beginning of implementation of ASEAN Economic Community (AEC), and the economic development of ASEAN plus one FTA with countries potential to be partners of economic development of ASEAN, local government's role in the implementation of standards, conformity assessment, and metrology is getting more vital regarding that local competitiveness serves as a key indicator in national competitiveness.

\section{Strengthening of Local Policies in National Standardization}

In the era of local autonomy, local government has great discretion to determine policies regarding local development. The government may allocate its resources based on the determined priority. To encounter future competition, the local government can take initiative by directing resources to improve competitiveness. The required initial step is mapping the potential of local areas (input factor) and the intended objectives (output factor), while the subsequent step will be determining the policies. In the context of standardization, input factor involves mapping potential of leading local products which serve as domestic commodities and export products, while output factor includes improving both national and international competitiveness to gain access to global markets. A guidance, or policy direction, is therefore required to function as a guideline to achieve the output factor.

Local autonomy gives authorities to local areas to govern itself and manage affairs of local authorities. The local government is given an authority to make local policies to provide services, improve its roles, initiative, and society empowerment for the purpose of the improvement of the wellbeing of society by considering society's interests and growing aspirations.

In addition, we need to be concerned on the results of research conducted by Veredigna M. Ledda, a supervising research specialist from Philippine Institute for 
Development Studies. Philippine's keys of success as one of ASEAN countries in the determination of Standards and Conformity Assessment are capacity building and strengthening of regulatory institutions (Ledda, V. M., 2012: 172). The results of research entitled Pemberlakuan SNI Secara Wajib di Sektor Industri :Efektifitas dan Berbagai Aspek Dalam Penerapannya carried out by Eddy Herjanto from BPKIMI Ministry of Industry of the Republic of Indonesia are interesting to examine. They revealed that $40 \%$ of aspects influencing effectiveness of mandatory SNI is aspect of local regulations. The drawbacks of such aspect are caused by weak support on policies at local level.

The findings of the research conducted by Veredigna M. Ledda and Eddy Herjanto seem to give a signal for the importance of local policies for the effectiveness of implementation of standards. Standards play a vital role in competitiveness and in entrance of global markets. For that reason, the strengthening of local policies in national standardization is highly required. Some attempts to strengthen local policies include:

a. Constructing local regulations regarding Standards and Conformity Assessment

According to Jimly Asshiddiqie, good construction of a regulation should be underlaid by philosophical, sociological, juridical, political, and administrative aspects and its enforceability should be reflected philosophically, sociologically, juridically, and politically (Asshiddiqie, J., 2006 : 243-244). Furthermore, Law Number 12 of 2011 regarding the Construction of Statutory Laws explains that to construct statutory laws, several considerations should be paid attention to, particularly those stipulated in Chapter IV of Annex of Law Number 12 of 2011 concerning Philosophical, Sociological, and Juridical Foundations.

The philosophical foundation represents considerations or reasons which convey that a constructed regulation considers way of life, awareness, and legal ideals including spiritual situation and philosophy of Indonesian nation sourced from Pancasila (the Five Principles) and the Preamble of the 1945 Constitution of the Republic of Indonesia.

Sociological foundation involves considerations or reasons which convey that a regulation is constructed to meet the needs of society in many aspects. It actually deals with empirical facts regarding growing problems and needs of society and state. 
Juridical foundation refers to considerations or reasons which convey that a constructed regulation is intended to overcome legal problems, or to fill legal emptiness by considering the existing regulations, which will be changed, or eliminated to guarantee legal certainty and society's sense of justice. The juridical foundation deals with legal problems associated with regulated substances, or materials, and therefore a new statutory law needs to be drafted. Some legal problems may include the presence of old regulations and inharmonious or overlapped regulations, the weak validity of a regulation due to its lower hierarchies than Law, insufficient existing regulations, or the absence of regulations.

In the context of standardization, constructing a local regulation concerning Standards and Conformity Assessment is an attempt to realize national competitiveness and to improve local society's economy. Such fact is in line with the ideal and purpose of the state as stated in the Preamble of the 1945 Constitution: enhancing social welfare. In addition, the construction of local regulations regarding Standards contradicts neither values of Pancasila which include values of divinity, humanity, unity, democracy, and social justice, nor the existing local moral values. In short, the construction of local regulations regarding Standards and Conformity Assessment entails philosophical foundation.

Indonesia's low level of competitiveness and of adherence of business actors to implement the $S N I$, as well as free trade era have become sociological foundation to construct local regulations concerning Standards and Conformity Assessment. Local governments are concrete forms of laws. Statutory laws shall be constructed based on actual situations, phenomena, development, and belief, or awareness, as well as legal needs of society. Apart from that, society also requires local regulations which serve as main references and methods of the implementation of the SNI, whereas in fact development in sector of industry by local government is partial and unintegrated. Various policy programs to improve competitiveness of leading local products are implemented without any references, models, and implementation of Standards and Conformity Assessment by all components of a local area, including local government, the BSN, Certification Institute, State-owned Enterprise, and cooperation. The presence of local regulations regarding Standards and Conformity 
Assessment will lead to more directional, systemized, and comprehensive implementation in the field of local industry.

Some related statutory laws which serve as juridical foundation of the construction of local regulations concerning Standards and Conformity Assessment include: Article 33 of Law of the Republic of Indonesia of 1945, Law Number 36 of 2009 concerning Health, Law Number 8 of 2012 concerning Food, Law Number 3 of 2014 on Industry, Law Number 7 of 2014 regarding Trade, Law Number 20 of 2014 on Standards and Conformity Assessment, Law Number 23 of 2015, as amended by Law Number 9 of 2015 on the Second Amendment of Law Number 23 of 2014 regarding Local Government.

Local regulations on Standards and Conformity Assessment possess strong juridical, sociological, philosophical foundations of validity to construct local regulations regarding Standards and Conformity Assessment. Such regulations can serve as a comprehensive legal umbrella for the implementation of Standards and Conformity Assessment to support competitiveness of local industries.

b. Implementing policy of SNI-compliant leading local products

Batik, wood sculpture, silver, copper, leather, weaving, pottery handicrafts, and ceramics belong to leading local products which have gone global. There are many leading local potentials which need to be developed and introduced in global markets. For that reasons, several attempts to improve competitiveness and access to global markets need to be made.

Regulation of Minister of Domestic Affairs Number 9 of 2014 on the Guideline for the Development of Leading Local Products defines leading local products as any products, comprising either goods or services, produced by cooperation, small and medium scale enterprises which are potential to be developed by making use of such local resources as natural resources, human resources, and local culture, produce revenue for both society and government, and are expected to be economic strength for local areas and society as potential products with competitiveness, selling power, as well as driving force to head to and enter global markets. 
The regulation also regulates local government's responsibilities in developing leading local potentials. According to the regulation, the development refers to attempts made by government, local government and society to develop leading local products through planning, organizing, funding, supervising, controlling, and activity evaluating.

In the context of development of leading local potentials, local government is responsible not only for identification of the leading local products as development process of local resources and optimization of local economic potentials, but also for the strategy for the development of leading local products to gain high level of competitiveness and access to global markets. The implementation of mandatory SNI to leading local products can be an effective strategy to improve competitiveness, and consequently to develop local economy.

The implementation of mandatory SNI to leading local products is underlaid by several considerations: To begin with, the implementation of mandatory SNI to leading local products can be an access to global markets. TBT agreement, WTO and ASEAN MEA Blueprint set requirements for the implementation of Standards and Conformity Assessment for local products to enter the markets of the country members. Therefore, local policies to formulate mandatory SNI are important to carry out. On one side, the leading local products play a crucial role since they give the greatest contribution to local revenues, particularly to own-source revenues. For that reason, the implementation of mandatory SNI to the leading local products should receive special attention and be prioritized. Moreover, there are many more leading local products which have not been identified to be potential local products to develop.

Second, the implementation of mandatory SNI to leading local products aims at not only gaining access to global markets, but also protecting domestic markets from 'invasion' foreign products. In addition to protecting consumers from low quality products, the implementation of mandatory SNI to leading local products is intended to protect domestic business actors from unfair competition.

In the context of standardization, each manufactured product guarantees its standards of quality since each producer has quality target of the manufactured 
products to compete in a fair competition. If there is no mandatory SNI to leading local products, it is likely that in era of free trade, other countries export similar leading local products to the same markets. The invasion of Chinese batik in 2013 in Indonesian market and local markets has become necessary lesson on the importance of the protection of leading local products in domestic markets.

c. Strengthening mutual cooperation among local government and the $B S N$, private companies, state-owned enterprises, cooperation, the BPOM, and higher education institutions

The success of national development in the field of standardization requires supports from cross-sectors in addition to strong commitment of both central and local governments, as well as active participation of society, enterprises, and higher education institutions. The implementation of strengthening of standardization in local areas certainly requires the strengthening of cooperation and coordination among stakeholders. Local government's roles should be strengthened since it is considered as a party closer to production center of leading national commodities. The division of roles between central and local governments should be wellmanaged to avoid inefficiency of standardization.

To formulate standards, provide guidance for the $L P K$, and improve human resources, local government is expected to continuously develop cooperation with association of business actors. The cooperation between both parties entails strategic meanings. The strategic roles of the association in determining standards involve: (1) disseminating information about statutory laws on Standards to members/ business actors, and (2) encouraging members/ business actors to produce and trade goods/ services according to the provision of standardization to guarantee quality of the goods/ services.

Local government can also develop mutual cooperation with higher education institutions by holding trainings on product developments according to standards, and activities of research and standard development. Data of research and development in the field of standardization can be basis data which if required can be used as the foundation of argumentation to strive for national interests in an 
organization which develops cooperation in the field of standardization at international level.

\section{E. CLOSING}

\section{Conclusion}

a. As an attempt to improve competitiveness, local government plays strategic roles in determining the implementation of Standards and Conformity Assessment for leading local products, including: (a) proposing the drafting of SNI to the BSN to improve quality of leading local products/ services; (b) providing guidance for the development of the $L P K$; (c) improving competencies of human resources in the field of Standards and conformity Assessment; (d) supervising goods, services, systems, processes, and personals with SNI certificate and/or compliance with SNI and/or certificate of conformity.

b. Several strategies for strengthening local policies in national standardization include: (a) constructing local regulations regarding Standards and Conformity Assessment; (b) implementing mandatory SNI to leading local products; (c) strengthening cooperation among local government, the $B S N$, private companies, state-owned enterprise, cooperation, the BPOM, and higher education institutions.

\section{Suggestions}

1. Standards and Conformity has recently become a strategic issue in the context of international trade since the issue goods/ services' quality presents as a central issue which determines access to a country's market. In the context of WTO and AEC, the fulfillment of standards of goods/ services serves as the key to support the market entry. For that reason, strengthening local government's roles by involving it in the construction of SNI should be done as an attempt to improve competitiveness of leading local products since it is regarded as a party closer to production center of leading national commodities

2. Several strategies to strengthen the implementation of Standards and Conformity Assessment is impossible to perform without the presence of supports from several parties, in the aspect of either availability of facilities and infrastructures, or policies. Several aspects can strengthen the implementation of standards: (a) the development of the $L P K$, calibration laboratory, Inspection Institute, Certification Institute in all local areas having leading local products; (b) minimization of SNI testing costs and 
acceleration of time and procedures of SNI testing; (c) policy consistency of the implementation of mandatory SNI; and (d) massive and systematic socialization to ensure that information about potential of leading local products, and the effectiveness and benefits of the implementation of standards is delivered to all local stakeholders.

\section{BIBLIOGRAPHY:}

\section{Books and Journals:}

McDaniels, D., \& Karttunen, M, 2016, Trade, testing and toasters : Conformity assessment procedures and the TBT committee. WTO Working Paper ERSD-2016-09, World Trade Organization Economic Research and Statistics Division.

Herjanto, E, 2011, Pemberlakuan SNI secara wajib di sektor industri: Efektivitas dan berbagai aspek dalam penerapannya. Jurnal Riset Industri, Volume 5 Number 2.

Asshiddiqie, J, 2006, Perihal Undang-Undang, Jakarta: Konstitusi Press.

Marzuki, P. M, 2014, Penelitian hokum, Jakarta: Prenadamedia Group.

Veredigna M. Ledda, 2012, AEC 2015: Issues and challenges in Standards and

Conformance. Philippine Journal of Development, 71, First and Second Semesters 2012 XXXIX (1\&2).

\section{Regulations:}

Asean Policy Guideline on Standards And Conformance

The Agreement on Technical Barriers to Trade (TBT Agreement)

Law Number 12 of 2011 On The Construction of Statutory Laws.

Law Number 20 of 2014 On The Standards and Conformity Assessment.

Regulation of Minister of Domestic Affairs Number 9 of 2014 on the Guideline for the Development of Leading Local Products

\section{Internet:}

http://finance.detik.com/berita-ekonomi-bisnis/d-2175015/ri-digempur-batik-china-sejak-4tahun-lalu Retrieved on 2017, July 20 at 16:11 Indonesian Western Time. 